\title{
Ki AgENG SURYOMENTARAMAN, JAVANESE PRINCE AND PHILOSOPHER $(1892-1962)^{*}$
}

\author{
Marcel Bonneff
}

The Javanese love of religious and philosophical contemplation is clearly seen in the many groups, associations, and movements whose common goal is the realization of a certain spiritual fulfilment. A summary generalization, however, runs the risk of distorting "Javanese spirituality." The vast "corpus" of ideas and doctrines must be considered in all its diversity. ${ }^{1}$ This article sets out to study the philosophy-the so-called "science of the psyche" - of the "dissident" Prince K.A.Suryomentaraman (KAS) and to show that, although such thoughts are original, when set in their social context, they can be seen to be the expression of a certain mentality.

\section{Suryomentaram's Legacy}

One of KAS's close friends relates how he had pointed out to KAS the value of having his writings translated into Indonesian, or indeed into a foreign language, so that his philosophy might enjoy the recognition it deserved. This conversation took place shortly before KAS's death, while he was in hospital in Yogyakarta. The Javanese philosopher reacted forcefully. Were there not already enough people seeking popular acclaim? In their efforts to commend him, were not those around him merely seeking to boost their own self esteem and reputation? Such a reply demonstrates KAS's faithful adherence to the simple, disinterested style of leadership he had fashioned more than thirty years earlier. ${ }^{2}$

It is now fifteen years since his death; there are still many people alive who knew him, many who continue to think of themselves as the Pelajar Kawruh Jiwa, "disciples" of this

\footnotetext{
"The French version of this article appeared in Archipel 16 (1978): 175-203.

${ }^{1}$ In this field, Archipel (No. 4, 1972) has already published, a study of the Pangestu Movement by J. Indrakusuma.

2 S. Wirjosoedojo, "Sapa Kang ngedegaké PETA?" Mekar Sari 19,17 (November 1, 1975): 13-14.

${ }^{3}$ For dialectal words and quotations the current forms of both the Indonesian and Javanese languages have been used. In Javanese the double orthographical signs $d h$ and th have been used to denote retroflexes. Proper names and book titles have, however, been cited as found; nonetheless, the current practice of writing the names of
} 
"science of the psyche," as KAS never tired of defining it, conference after conference. Such definitions have been recorded in short articles, still sometimes to be found on the bookshelves of private homes and in second-hand book collections. Recently the Idayu Foundation undertook the publication of these articles in Indonesian, so that vast numbers of readers (and in particular non-Javanese speakers) might have access to ideas which the editor compares to those of Socrates, Zarathoustra, and Krishnamurti. To recognize the "international dimension" of such praise is not, however, to conceal the fact that this publication (whose editor is very closely linked to government circles) probably owes its origins, at least in part, to the official intention to reveal a vision of existence which is heavily imbued with "Javanism."

The elder son of the philosopher, Dr. Grangsang Suryomentaram, who continues to head the Kawruh Jiwa Movement (or Kawruh Beja, the "Science of Happiness"), is for these two reasons the one best able to keep alive his father's memory. Recently, several articles written by himself or his late father's friends have been published by the press about KAS's life and work. However, in these articles, KAS's warning about the danger of "hagiography" does not seem to have been fully understood. ${ }^{4}$ In addition to recalling his philosophical ideas, these articles assign an important place to KAS's role as a nationalist, clearly demonstrated by his participation in Paguyuban Selasa Kliwon-a patriotic cause which inspired the educational movement Taman Siswa-as well as his widely believed role as creator of the PETA and the lec'ures extolling nationalism he delivered after Independence. This renewed interest in a person who lived through contemporary history without ever appearing at the forefront of the political stage seems, nevertheless, to indicate that he exercised a considerable moral influence. ${ }^{5}$

\section{The Prince's Disillusion}

In trying to piece together KAS's biography and clarify his role, one is dependent on very limited and unconfirmed sources, insofar as the story of his life sometimes appears to be told for allegorical purposes. 6

Born on May 20, 1892 in the Kraton of Yogyakarta, he was the 55th of Sultan Hamengku Buwono VII's 79 children. His mother, B.R.A. Retnomandoyo, a second ranked wife (garwa ampeyan) was the daughter of the patih Danurejo VI. Having completed his primary education at the Srimenganti Palace School, he went on to prepare for the Klein Ambtenaar (junior civil servant) examination, which enabled him to take up an administrative position at the

certain well-known persons according to the rules of ejaan baru has been followed: Suryomentaram (Soerjomentaram) is a case in point.

${ }^{4}$ Reference to articles will be made as and when they occur. A complete reference of KAS's works can be found at the end of the article.

${ }^{5}$ For example B.R.O'G. Anderson in his otherwise very detailed study of the political events of the period 19451946, which took place for the most part at Yogyakarta, makes no mention of Suryomentaram (Java in a Time of Revolution: Occupation and Resistence (Ithaca, Cornell University Press, 1972]).

6 In particular, use has been made of Dr. Grangsang Suryomentaraman's articles which appeared in the Jakarta newspaper Berita Buana: "Riwayat singkat Ki Ageng Suryomentaraman" (July 24 and 25, 1975), and "Rahasia di balik pembentukan Tentara Pembela Tanah Air (PETA)" (July 19, 1975), Ki Atmosutidjo's work, Ganḍulan kanggé kontja-kontja peladjar Kawruh-djizwa and Kjai Pronowidigdo's article entitled "Riwajatipun Kawruh Djiwa,"

published in Buku Peringatan ... (cf. bibliography). There is also a biography of KAS by Ki Djojodinomo, but this source has not been used.

M. Agus Suwito and Dr. Grangsang kindly allowed use to be made of a number of documents and the author would like to thank Dr. Grangsang and $\mathrm{Ki}$ Haditomo for the information they related to him (interviews May 1975). 
Yogya Residence; he appears to have held this position, for which he needed a knowledge of Dutch, for just two years. He also learned Arabic-in the course of his religious studies? $\rightarrow$ and later English, and is said to have made up for his lack of formal education by prodigious reading.

At the age of 18 he became a Prince, exchanging his title and name (Bendoro Raden Mas Kudiarmaji) for that of Bendara Pangéran Harya Suryomentaram.

Little else is known about his early life. He himself was to relate how he was struck by the back-breaking work done by the field laborers he glimpsed through the train window one day on the way to a wedding ceremony at the court of Surakarta: whilst others were suffering extreme hardship, he and others like him, were getting ready to partake of the splendors reserved for those of noble birth. But, as his closest friend, Prawirowiworo, was later to remark, were those peasants any unhappier than the Prince himself, who could feel rather more sorry for himself than for them, since they at least were satisfied with their lot? Prawirowiworo (who died in 1960) was the Prince's confidant, the oldest and closest of his friends. The two men were cousins; but as Prawirowiworo's rank was much lower, he was employed as a servant at the Sultan's Palace.

On the one hand, there was the Prince, showered with honors and riches, on the other, the abdi dalem whose very small salary barely enabled him to discharge his duties. Both men, however, were dissatisfied: neither had ever "known Man" ("saprana-sapréné aku kok durung tau kepethuk wong"); the Prince knew only his masters and their tempers. The sheltered life he had led was the main reason for Suryomentaram's feeling of dissatisfaction. As a result he absented himself more and more often from the kraton to go to meditate in various places believed to be propitious (the Goa Langse or Goa Cermin caves, the beach at Parangtritis, and certain kramat tombs). Prawiro, whose duties were now less onerous, began also to travel about. They told each other of their respective experiences. Sometimes they shut themselves away to pray. At other times they went to talk to spiritual leaders and were keen to learn about things of a religious or mystical nature.

The Prince's entourage became worried: believing material possessions to be an obstacle to happiness, he began to give away his personal property. So it was that one of the wealthiest princes in Yogya gave his car to his driver, his horses to his groom. ... Then one day he fled the kraton; dressed as a merchant and using the name Notodongso, he traveled about the Cilacap region selling batik. His father, the Sultan, sent men to look for him. They found him at Kroya digging a well and brought him back to the kraton.

These events took place while the Prince was in his twenties and before 1920, the year when an official letter was sent by the Resident Jonquière to the Governor General, together with a translation of a letter from Suryomentaram in which he asked to renounce his title of Prince. He had asked his father's permission which was refused, as was his request to be allowed to make a pilgrimage to Mecca. ${ }^{7}$ But that year, his biographers tell us, Suryomentaram was in a state of utter confusion: in just a few months he had seen his grandfather, the patih Danurejo, relieved of his office and his mother divorced by Hamengku Buwono VII; finally and most importantly his wife had died, just after giving birth to their son.

\footnotetext{
7 The document is dated August 21 and KAS's letter August 14, 1921 (Mailrapport No. 948 Geheim/1920; verbaal dated 6-1-21, No. 81). In his letter the Resident stresses that he tried himself to dissuade the Prince. The author is indebted to Mr. Kenji Tsuchiya for making this document available to him. This document is also relevant to Mr. Tsuchiya's own research into the history of the Taman Siswa Movement; see his article: "The Taman Siswa Movement. Its Early Eight Years and Javanese Background," JSEAS 6, 2 (1975):164-77.
} 
In 1921 the Sultan abdicated and his successor, Hamengku Buwono VIII, agreed to allow Suryomentaram to leave. The Prince refused to accept the allowance proposed by the Dutch and instead made do with the small annuity paid to him by the sovereign. Having disposed of the last of his possessions, he settled down in the village of Bringin, near Salatiga, where he bought some land. Henceforth, he was to lead the life of a petani, like those he had originally seen laboring in their rice fields. In 1925 he remarried. His reputation grew. Ki Gedhe (or Ageng) Bringin ${ }^{8}$ was certainly an eccentric personality. Some people believed him to be a dhukun and came to seek his advise. He had long since given up his royal robes in favor of the black shorts and leather belt worn by the peasants; he went about barefooted, of course, but around his neck he wore a length of batik cloth dyed with the parang rusak barong motif, which was then still worn only by the sovereign. Such a gesture is indicative of a certain dissatisfaction; some years earlier in the same spirit Suwardi Suryaningrat had had his servants wear a similar kind of kain when they went into town. ${ }^{9}$ Suryomentaram was again to be considered a figure of curiosity because of his clothes and strange behavior at his father's funeral (1931); at Imogiri, where the ceremony took place, his former family and friends thought him mad; they moved away from him; Suryomentaram frightened them.

One day, dressed as ever in shorts and with bare feet, as he was about to board a bus, he was taken for a porter: a traveler gave him his suitcase, which he took and carefully stowed away ... thus foregoing his journey for fear of embarrassing the honest traveler. Such was Suryomentaram; or at least such were the stories told about him, ${ }^{10}$ a man more attentive to others than himself, or rather so mindful of himself that he could see his own embarrassment in another's unease.

In fact Ki Ageng had never given up his quest for "Man." One night in 1927 he wakened his wife saying "I have found what I was looking for . . . it's Suryomentaram who is discontented; he's the disillusioned pangéran, the dissatisfied merchant, the disappointed peasant; he's the source of disappointments (tukang ora puas). He has been unmasked (konangan). Henceforth I will always be able to find the man who bears the name of Suryomentaram." If Dr. Grangsang is to be believed, this was more or less what Ki Ageng said to his wife lying beside him. KAS had discovered the source of his problems: the confusion between the active-self and the passive-self; it is the passive-self one must at all costs learn to recognize and cultivate in oneself so as to avoid the trials of everyday contingencies and achieve "lasting happiness." "What I have been searching for, and have failed to find, is the concept of man (gagasan wong) who in fact exists only in my imagination." 11 The "Science of Happiness" (Kawruh Beja) was born. KAS was to convert his companions, of whom Ki Prawiro was the first, and then win over an ever-increasing number of followers.

It is relevant now to consider those aspects of KAS's career more immediately concerned with politics. To do so, however, it is necessary to return to the years 1921-22. At that time he was the leader of the Paguyuban Selasa Kliwon, which took its name from the day on which meetings were held; this group is well known as the originator of the Taman Siswa

\footnotetext{
${ }^{8}$ Suryomentaram means "Sun (surya) of Mataram." Ki is a term of address used by working class people when addressing elderly men renowned for their wisdom. (Nyi is used for women; as with kiyai and Nyai, although these two words have Islamic conotations). Gedhé-or Ageng - means "Great." Several people (real or legendary) in Javanese history have had such a title: Ki Ageng Séla, Ki Ageng Pamanahan, etc.

${ }^{9}$ Cf. Pranata, Ki Hadjar Dewantara perintis perdjuangan kemerdekaan Indonesia (Jakarta: Balai Pustaka, 1959), p 36.

${ }^{10}$ Interview with Ki Haditomo.

11 Cf. articles by Grangsang S. and Ki Atmosutidjo.
} 
Movement. ${ }^{12}$ There were nine priyayi, among whom mention should be made of Suwardi (Ki Hajar Dewantoro), the faithful Prawirowiworo, B.R.M. Subono (KAS's youngest brother), and Pronowidigdo. Some of them, such as the future Ki Hajar, or in fact Pronowidigdo, ${ }^{13}$ had the opportunity on many occasions to air their nationalist convictions (through their participation, amongst other things, in the Budi Utomo). The group (Paguyuban) was run along the lines of a "kebatinan society," 14 but the business at hand was clearly defined: deliberation on the means of winning independence. In 1922 the group disbanded after reaching agreement that liberation was to be achieved through the development of the general level of education and the national consciousness of the Indonesian people. The educational initiative was of prime importance. Ki Hajar Dewantoro was to be responsible for young Indonesians, and here he is well known for organizing their formal education (opening the first Taman Siswa school on July 3,1922). KAS was himself to be in charge of "adult instruction."

Some years later, in 1930, KAS was amongst the founders of the Pakempalan Kawula Ngajogjakarto whose president was Prince Suryodiningrat. This too was a movement whose humanitarian and social initiatives were of greater importance than its political objectives. The committee, made up of Prince Suryodiningrat and the enlightened priyayi, with the agreement of His Majesty Hamengku Buwono VIII, fixed on the objective of improving the general living standards of the sultanate's peasants: until the outbreak of war in the Pacific, the PKN-and similar organizations which arose out of it, and which likewise advocated autonomy and democratization for the administrations of the "principalities"- took several very popular initiatives which attracted large numbers of penniless farmers to its ranks: ${ }^{15}$ these included the setting up of agricultural cooperatives and lurik factories, propositions to revise the taxation system, elimination of illiteracy etc. In 1931 it joined forces with organizations (PPPPA and PPII) which were protesting against the practice of buying and selling women and children and, in 1932, with groups such as the Budi Utomo, Taman Siswa, and even Muhammadiyah, to protest against the Wilde Scholen Ordonnantie. ${ }^{16} \mathrm{At}$ a meeting in

\footnotetext{
12 On this point, see in particular: Suratman, "Masalah kelahiran Taman Siswa," Pusara 25, 1-2 (1964); and Kenji Tsuchija, "The Taman Siswa Movement," pp. 166-67.

13 Ki Pronowidigdo (Prono) died recently in Yogyakarta aged 96 (see Mekar Sari, May 1, 1976). A trained teacher and committed nationalist, he was among the earliest members of the Budi Utomo and was their spokesman in Yogya around 1920. He was closely associated with both KAS's and Ki Hajar Dewantoro's undertakings; he is thought to have been a founding member of Taman Siswa; until his death he was a respected and valued counselor. It should be noted that Ki Prawirowiworo was also a member of the first Taman Siswa Committee. 14 Kebatinan can be translated as "spiritual life." Many societies and groups are known to exist in Java whose members consider a knowledge of the "inner self" the fundamental element in the search for the Absolute. In general, the theoretical philosophy borrows a number of principles from Indian religious and/or Muslim mysticism, which are often expressed in esoteric terms. The "practical" aspect places great importance on meditation and certain contemplative exercises, indeed asceticism. But the concept of kebatinan (or Kejawen as the Javanese would say) may in fact encompass very diverse approaches, some of which claim to be "scientific." A common denominator might be, as will be seen later, the principal concept of psychological wholeness.

15 In 1938 the PKN numbered 253,218 members (of whom 30,471 were women), almost all of whom were peasants (90 percent). The other organizations were the Pakempalan Kawula Surakarta (set up in 1932), the P.K. Mangkunegaran (1933), and the P.K. Pakualaman; see Ensiklopedi Indonesia, pp. 926-27.

16 A colonial decree which strengthened control over "local" schools and limited their numbers. For the PKN's activities, see the book published to celebrate the organization's eighth anniversary (satu windu): Boekoe pengetan windon Pakempalan Kawoela Ngayogyakarta (PKN), 1930-1938, ed. PKN (1939), 103 pp. During the Japanese occupation and after Independence, the organization's founder, Prince Suryodiningrat, appears to have followed a rather more spiritualist course; he was considered an inspired guru kebatinan and the meetings he organized were eagerly attended by a large number of "followers." However, the PKN was again to become a political force in 1951, as the Gerinda party, whose members, according to Selosoemardjan, still viewed (in 1955) the
} 
$1932 \mathrm{Ki} \mathrm{Hajar}$ put forth his ideas on education and Ki Ageng explained the principles of the "Science of Happiness," putting particular stress on the fact that all men are involved in the same search for psychological well being and that the effect of such an experience was to put everyone on an equal footing.

When the Japanese entered the war, KAS was a member of a group of 13 nationalists (Manggala 13) ${ }^{17}$ who were planning the course of action to be followed in the event that fighting broke out on Indonesian soil between the Dutch and the "liberators of Asia." But when Java fell to the Japanese, the invaders encountered no opposition. The occupying force soon began to take an interest in KAS's activities (the Dutch had also had suspicions about him). Amongst those officers who came to call on him, a certain Asano (a member of the Secret Service) remarked that Suryomentaram gave the impression of being grateful to the army which had freed the Indonesian people from the yoke of colonialism and that, subject to receiving appropriate training, he and his friends would be prepared to fight alongside the Japanese. The former Prince defined what he called "Jimat Perang" (literally "a fetish for war"), as that absence of fear in the face of death which is the source of military courage. He was invited to speak on Jakarta radio and authorized to hold meetings to spread this idea. In the capital in 1943, thanks to the intervention of Mr. Sudjono, he met the group of four nationalists whom the Japanese trusted (Empat Serangkai: Sukarno, Hatta, K.H. Mas Mansur, and K.H. Dewantoro). On this occasion he appears to have convinced Sukarno to adopt the idea of Jimat Perang as his own; the nationalist leader was to refer to it on many occasions.

The Japanese, however, remained skeptical as to the possibility of forming an Indonesian militia; hence the categoric refusal given by the military governor of Yogya, Colonel Yamanuchi, to KAS's request to set up such a force. This being the case, Asano proposed laying the matter before the Emperor himself. KAS assembled eight of his companions to draw up a kind of petition which each of them signed in his own blood. To the surprise of the occupying authorities, Tokyo gave its approval. Ki Ageng would himself have begun to sign on volunteers, but the military government quickly took over the recruitment and training of this army known as the PETA (Pembela Tanah Air: Defenders of the Fatherland).

This version of the PETA's origins (an organization which was to play an important part in the attainment of Independence and whose officers were to form the backbone of the new Indonesian Army) has recently been disclosed by Dr. Grangsang. ${ }^{18}$ It is partially substantiated by statements made by Ki Prono and Ki Asrar Wiryowinoto, two of the petition's signatories. ${ }^{19}$ But, even if the conception of Jimat Perang was in fact inspired by KAS, many doubts remain about subsequent events and the role of the petition; in any event this is the conclusion reached by S. Wirjosoedojo-another of KAS's old friends-who disputed this version of events and who was unable to obtain $M$. Hatta's confirmation that the meeting

party's role as"following the ways of mysticism, namely, the unity of man and God, materialized in this world by the unity of subject and King and practiced in the Gerinda by the unity of party member and party president." (Social Changes in JogJakarta [Ithaca: Cornell University Press, 1962], pp. 188-89).

17 The manggala is the invocation at the beginning of a poem. The word also has the connotation of "avantgarde." Amongst this group's 13 members, it is interesting to note again the presence of Ki Hajar, Ki Prono, and Suryodiningrat, together with that of Radjiman Wediyodiningrat, Sutopo Wonoboyo (one of the founders of Taman Siswa), etc. (Berita Buana, July 25, 1975).

18 Berita Buana, July 19, 1975.

19 "Sapa kang ngedegaké PETA?" Mekar Sari 19,15 (October 1, 1975). 
between KAS and the group of four ${ }^{20} \mathrm{did}$, in fact, take place. Such an account is also puzzling in view of all that has already been written about the matter either by historians or other direct witnesses, and in particular by Gatot Mangkupradja, who is usually credited with having initiated this organization. ${ }^{21}$ The matter remains open to debate.

However, despite the fact that KAS's son's version of the events may be disputed, it is quite interesting for the light it sheds on Ki Ageng as an active participant in the struggle for Independence and thus an ardent nationalist. Of this there can be no doubt, his readiness to take up arms during the period 1947-1949 at the head of a Pasukan Rakyat Jelata detachment to confront the Dutch Army near Yogya being well known.

With the restoration of peace, he left his farm at Bringin, which had been devasted in the fighting, and went to live in Yogya, where he devoted himself to his philosophical teachings until his death at the age of 70 . In his telegram of condolences, President Sukarno paid tribute to him on behalf of the nation. 22

\section{KAS's Philosophy}

Like his life, KAS's writings are characterized by the idea of a search for a certain "happiness," or more particularly a psychological state of mind which resembles a kind of "spiritual detachment." At first commonly known as Kawruh Beja, this philosophy was later more often called Kawruh Jiwa ("Science of the soul / of the psyche" or Selfknowledge). The change of terminology, which aimed rather to focus attention on the means of achieving such knowledge, undoubtedly corresponded to its founder's deepening reflection. ${ }^{23}$

The basis of the "Science of Happiness," indeed its principal axiom, is the recognition of human existence as an interchange of joys (bungah) and sorrows (susah). The feelings of happiness (raos beja) and unhappiness (raos cilaka) which such states of mind produce are what differentiates man from other animals. Although man is subject to the same vital needs as other animal species-assuring his survival (pangupa-jiwa) and that of his race (lestantuning jenis)-he is different from them because he is aware that he has these needs (raos gesang: awareness of life). Thus, for man, satisfying or failing to satisfy basic needs is linked to the concepts of happiness and unhappiness. Moreover, once his primary needs are met, man becomes aware of secondary needs which are the figment of his imagination. KAS cites as an example of a man's imaginary needs the idea which persuades him to prefer tea to coffee or beer, when any kind of liquid (water) would quench his thirst, a primary need felt equally by everyone. Thus man becomes the victim of his supposed needs which result in his desires (karep) exerting such a powerful influence on his life that he confuses desire with true human existence: "Man equals longing" (Karep punika tiyang); "Whilst still in his

\footnotetext{
${ }^{20}$ Wirjosoedojo, "Sapa kang ngedegaké PETA?" Mekar Sari 19, 17 (November 1, 1975).

21 See in particular: Nugroho Notosusanto, The Peta-Army in Indonesia, 1943-1945 (Dept of Defence and Security, Centre for the Armed Forces History, 1971), 23 pp.; and Raden Gatot Mangkupradja, "The Peta and My Relations with the Japanese: A Correction of Soekarno's Autobiography," Indonesia 5 (April 1968). It is interesting to note that Gatot (who died in 1968) claims also to have sent a request signed in his own blood.

22 See Kus Sudyarsana, "Kawruh Bedja," Mekar Sari 6, 3 (April 1, 1962). KAS was buried beside his mother in the cemetery with the other Nitinegara descendants (Trah Nitinegaran), at Kanggotan (about $7 \mathrm{kms}$. south of Yogya, near the ancient city of Kerto, once Sultan Agung's capital).

${ }^{23}$ The writings which most particularly deal with the exposition of the general principles are as follows: Wedjangan Kawruh Bedja Sawetah (adapted into Indonesian under the title: Wejangan pokok Ilmu Bahagia), NgelmiKawruh-Pitedah sedjatining gesang wedjangan KAS (by M.Soedi), Pilsapat Raos Gesang (adapted into Indonesian as: Filsafat Rasa Hidup); Tandesan: Wedjangan Kawruh Bedja sawetah.
} 
mother's womb, the desire to be born is already present" (Nalika wonten wetenganing biyung sampun wonten karep lahir); desire is everlasting, eternal (karep punika langgeng), and since at times it generates happiness and at times unhappiness, these two feelings are as everpresent in man as his desire; they are man's eternity (man is eternal because his desire knows no beginning or end). 24

Some sort of law seems to govern the life of this longing: though a need may be satisfied, it may still give rise to new demands which may well grow more urgent (mulur), whereas an unsatisfied need is ever present, but may take the form of a less vital demand which grows less urgent (mungkret). Desire is influential in three clearly defined areas, "wealth" (sémat in the general sense of "material goods"), public recognition (drajat; one's place in the social hierarchy), and magic powers (kramat). The knowledge that one cannot be happy for more than three consecutive days renders the search for such things futile. KAS's other main postulate was as follows: "There is nothing on earth worth so much that it should be sought after or shunned at all costs." 25 All his writing is characterized by examples which underline this principle; a single illustration will suffice: a man had a child who was getting married and he wanted to offer his guests the best possible hospitality by organizing a wayang kulit for them; however, he did not have enough money and wondered anxiously how he might borrow some. If he could not manage to borrow any he would find himself in an embarrassing situation and feel ashamed (wirang). But this would not last long; once the ceremony was over, how relieved he would feel not to be in debt! ${ }^{26}$

The desire for sémat-drajat-kramat means that each one of us is guided only by his own self-interests and, by giving free rein to one's egoism, one does just as one pleases (sawenang-wenang); thus it is not only a source of personal anxiety (sumelang) and regret (getun), but also a cause of social competition and inequality. Those who have not are jealous (mèri) of those who have, whilst those who have, fearful of losing their possessions, take comfort in their sense of personal worth (pambegan) and despise those less fortunate. ${ }^{27}$

KAS describes "kramadangsa" as that part of us which drives us to seek our own well being without due consideration for others and often to their detriment ("mila kramadangsa punika mesthi pados sakéca pribadi lan mboten parduli tangga inggih punika ingkang murugaken sewenang-wenang"). ${ }^{28}$ It is this same kramadangsa which makes us believe in the reality of our desires, which prevents us from seeing the world as it really is rather than the image which we have of it. It buries deep in one's consciousness one's true Self, independent of all contingencies. In short, the "contingent-self" is balanced by the "essential-self" $(A k u)$. As a result of man's awareness of his existence and his predisposition for reflection and for furthering his knowledge, he is able to lower the veil (aling-aling) which conceals his inner being and so realize true self-awareness (raos aku).

We have seen how KAS one day succeeded in discovering his true self, a discovery which led him to declare: "Suryomentaram dudu aku" (Suryomentaram is not my self). To illustrate the effect of this "finding of his new Self," he liked to recall an incident which

\footnotetext{
$24 \mathrm{Cf}$. in particular Wedjangan, pp 22-24.

25 "Salumahing bumi sakurebing langit, punika boten wonten barang ingkang pantes dipun aya-aya dipun padosi utawi dipun ceri-ceri dipun tampik" (as for example: Tandesan, p. 20).

26 Wedjangan, pp. 3-4.

27 On the question of social relationships see in particular: Pilsapat Raos Gesang; Aku iki wong apa?; Ukuran kaping sakawan (adapted into Indonesian as: Ukuran keempat).

${ }^{28}$ Mawas diri, p. 23.
} 
marked his life: one day on the way to Parangtritis he was held up by the flooded Opak River. No boatman wanted to risk the crossing. KAS decided to swim across to the other side. But the torrent swept him away. As he was drowning, it became clear to him that his haste to make the crossing come what may, suggested a desire on his part to end his life (he had just lost his first wife). Suryomentaram's passionate nature, which was disappearing under the water, had nothing in common with the "serene-self" which was floating on the surface. 29 "This is not me" (dudu aku).

One must learn from experience (piageming gesang) to contrast moments of joy with moments of sorrow, to sharpen one's rasa. It is a matter of time and practice (latihan). The approach KAS suggests is none other than "introspection" (Pengawikan pribadi or mawas diri). ${ }^{30}$ This approach is a highly individual one, but where one may nevertheless depend on the help of others: to secure such help one has only to talk about oneself, to ask for the judgement of one's fellow student-companions, go back with them "from the effects to the causes." The feeling of happiness suggested is in no way the antithesis of unhappiness, rather it is the tranquillity (tentrem) and liberation (mardika) which ensues from such a standpoint in the face of one's existence. One should aim to find "self-awareness" not "happiness," which is but the result of it. Since it comes from one's innermost being (aku), this happiness is as lasting as one's self-awareness. Fortified by this wisdom, one's only possible course of action is to appear "resolute" (tatag), that is to assume one's destiny independently of circumstances ("no matter where, no matter when, no matter how"). To break free from the "diabolic" cycle of fear for the future-regret for the past, 31 to put an end to the interchange of happiness-unhappiness, one must act according to the principle of the six "sa": sabutuhé, saperluné, sacukupé, sabeneré, samesthiné, sakepenaké (in accord once with one's needs, with one's circumstances, with moderation and fairness, and in an appropriate and easy manner). If Suryomentaram preferred coffee rather than tea to quench his thirst, his "ego" ( $a k u)$ would just have to make do with a glass of water!

Personal stability is the prime requirement for social harmony. In fact, it is man's desires which persuade him to force his will on others or else to see himself as the victim of inequalities; one of KAS's favorite examples is taken from a family context: very often people are content just to pretend to love their children; their so-called love comes partly from the assurance of having descendants and partly from the fact that the parent can count on his child's help in the difficult days of his old age; he can also transfer to him all his hopes for success. ${ }^{32}$ If, for example, the child repeats a class, his parents are furious. The arguments they put forward are many, but the underlying reason for their anger is none other than their fear of seeing their hopes dashed. Thus parents should be aware of the true nature of their feelings and, consequently, understand that the source of their anger lies in themselves, in their own egotism, but that the child is stimulated by completely different motives. Then, their criticisms of him will be made not in anger, but in a peaceful atmosphere (raos dame) and account will be taken of all the reasons for which the child might be motivated not to work. This is real love; it is seen clearly when one puts aside one's own interests. It ensures harmony and highlights resemblances between parents and children

29 Gandulan, pp. 10-11.

${ }^{30}$ The book titles are self-explanatory: Piageming gesang [The Test of Existence]; Pangawikan pribadi [Selfawareness]; Mawas diri [literally: Being mindful of One's self].

31 "Luwar saking naraka sumelang lan manjing swarga tatag" (leaving the hell of regret-fear and entering the heaven of determination); Wedjangan, p. 30.

32 ". . gegayuhanipun inggih punika tandon pensiun lan garan moncèr," in Buku Peringatan ... (the article:

"Wudjuding Kawruh Djiwa"). 
(raos sami); in fact, disregarding individual instances, men, rich or poor, king or coolie, live through the ups and downs of life in the same way; everyone is equal from a psychological point of view. To know oneself one must know others, feel what they feel (ngraosaken raosing tiyang sanès). This social sensibility is what KAS termed the "fourth dimension" (Ukuran kaping IV). In the same way that one thinks "dudu aku" (this is not me) when one catches sight of oneself in all one's selfishness, so the fourth dimension is what prompts one to say "dudu kowe" (this is not you) when one sees what others have done. Love and mutual respect would be characteristic of a society in which the fourth dimension prevailed. ${ }^{33}$

Not content merely to define the general principles outlined here, KAS also held many meetings to look at specific ways in which his philosophy could be put into practice. The situations in which an individual may find himself vary throughout life (lelampahing gesang $)^{34}$ and he has various fields of interest, each one of which requires an appropriate response. In the order in which the author gives them, these centers of interest are: material possessions, public recognition, power, the family, group life, the nation, knowledge, "spiritualism" (kebatinan), and aptitudes (kesagedan; or "awareness of one's possibilities"). ${ }^{35}$ There are, furthermore, difficult periods dotted throughout the course of one's life: the awakening of feelings of love at adolescence, one's choice of spouse, certain situations related to married life, the education of children, one's approaching death. ${ }^{36}$ At each instance it is vital for man to be aware of his needs and to know what is hindering the development of his personality. Sexual desire, for example, should be accepted as the consequence of a vital need; it finds total fulfilment in marriage which is an appropriate context for procreation. Respect for one's partner, that is acceptance of his or her differences, should be the basis of married love (KAS insisted amongst other things on monogamy as well as parental love). ${ }^{37}$

KAS gives careful consideration to those situations which are among the most testing one faces in life (pengalaman pait getir): the death of parents or their divorce when one is young; the death of a brother, sister, or friend; illness; an unhappy love affair; an arranged marriage; poverty; the loss of social prestige, etc. He shows how a lesson may be learned from each occasion which will help us to maintain or re-establish our psychological equilibrium. ${ }^{38}$

Worrying about things of a metaphysical nature is a result of one's ignorance of man's true nature. Man's soul is as one with his desire, which has no beginning or end: it occupies a human form for a time, then disappears once again into the universe (Alam Agung). Why then worry about death? By looking closely at his desire, man will have been able to make the best of his life, because of his ability to distance himself from what is going on. It then matters little if he is reincarnated as a wild pig (cèlèng); such a creature's fate is different, but neither better nor worse than man's. Thus, it is absurd to seek to attain perfection (kasempurnan) in this life in the hope of a better life in the hereafter. Such a life does not exist; it does so only in our imagination, in answer to our unsatisfied desires which lead us to hope for eternal happiness. KAS, therefore, argued against the superstitions and religious beliefs such hope engenders ("superstition is a way of seeing relationships between causes and

\footnotetext{
33 Cf. Ukuran kaping sakawan.

${ }^{34}$ On this subject see in particular: Aku iki wong apa?

${ }^{35}$ Cr. Mawas diri, pp. 33-54.

${ }^{36} \mathrm{Cf}$. Piageming gesang.

37 On conjugal love and marriage, see Kawruh Laki-rabi; on children's education: Kazoruh pamomong.

38 Piageming gesang.
} 
effects which do not exist"). ${ }^{39}$ He thought the guru kebatinan's teachings "bizarre" (aneh), denounced the trust certain people put in the dhukun, and rejected the practices of fasting, sexual abstinence, etc. as unnatural. 40

Another important aspect of KAS's teachings deals with the life of the Indonesian nation. His readiness to work alongside the nationalists for whom independence was contingent upon intellectual progress has already been recounted; likewise his active support of the "enlightened" artistocrats who sought the emancipation of the sultanate's peasantry, and finally of the rebels when the country's fate depended on the use of force. His political beliefs always reflected one of his major concerns: respect for others as a measure of one's own self-respect. To explain the colonial reality, he had only to put his conception of individual existence on a national footing. If Indonesians had been able to suffer the yoke of colonialism for so many years, it was not because of any violent domination (angkara-murka) on the part of the Dutch, still less because it was their destiny (sampun pinasthi); it was simply because, divided as they were, they had no national identity. What is a nation? How should the lives of men who share a common interest be organized? What is the role of such a group's culture? Is the group's cohesion determined by the degree to which its social functions complement each other? KAS's replies leave no room for doubt as to the need for a national recognition of individual responsibility in community affairs, a perception which can be summed up by the expression: aku duwé nagara, "I have a country of my own." 41

In the troubled world of the early 1950s, Indonesia's unity had to be particularly strong in order to avoid the trap of alternating between capitalism and communism, a trap laid by the two rival world powers for the newly independent countries. Keeping faith with the tenets of his philosophy, KAS explained to his listeners that states which feared the outbreak of a third world war, just as much as those which sought such an occurrence, believed they could deny the reality of their own problems by making them appear dependent on things outside their control. ${ }^{42}$

In the Pancasila, Indonesia has a collection of principles capable of giving rise to a new mental attitude and consequently of supporting national unity. The most important of the five principles is "popular sovereignty" (panguwasa rakyat) which KAS interpreted as the recognition of the individual's right to be free, or the triumph of a social spirit over those instinctive forces which lie dormant in each one of us ("the animal [cow)] which is in man"). From this point all the finest sentiments (raos luhur) embodied in the Pancasila are accessible to him: humanitarian sentiments, a spirit of nationalism, and a sense of justice. Finally, it should be noted that Belief in God appears in KAS's writing as a result of the four other principles, as the highest refinement of the social spirit; as far as this author knows, this is the sole reference to God throughout the whole of the philosopher's works. ${ }^{43}$

\section{The "Patriarch" and his Followers}

With obvious "pedagogical" concern, KAS reflected at length on the approach a person studying the "Science of the psyche" should take. ${ }^{44}$ First of all he must realize that this

39 "Guyon tuhon punika nyambet-nyambetaken sebab lan kedadosan ingkang mboten sambet," Wedjangan, p. 27.

40 Hal Kesempurnaan.

41 Pembangunan djiwa warga negara.

42 Perang dunia kaping III.

43 Raos Pantja Sila.

44 For the most part these procedures are explained in Tandesan. 
science is very simple in its principles, but also very difficult when it comes to putting it into practice.

Simple was indeed the way he described his thinking. It is a discourse steeped in imagery, where every idea is illustrated by examples drawn from everyday life, which runs the risk, at times, of seeming (to us) somewhat trivial. "A person who wants to ensure the continuation of his lineage must first have in-laws and then a child, which is not the case for bovines who do not have in-laws." 45 Constant recourse to allegory fits perfectly well with the idea that one's own experience is the primary source of the awakening of one's consciousnesse.

The elements of each different proposition are carefully defined and analyzed one by one. The rationale proceeds through a series of antitheses, according to a dialectic designed to arouse in the listener or reader the sense of harmony the dissertation is advocating.

Few foreign words or "Indonesianisms" are to be found. Although KAS invented his own particular terminology (Kramadangsa, ukuran kaping sakawan, raos sawenang-wenang, etc), in general he used a simple vocabulary, eschewing all literary devices. If his syntax is not always rigorous, this is above all due to the fact that his lectures were originally delivered orally, as well as, in part, to a predilection for paradoxical phrases.

In short, the stylistic techniques marry well with the author's intentions. They reflect his didactic attitude and attest to a determination to rationalize, which is in marked contrast to the gibberish found in many of the kebatinan doctrines; they also underline the respect $\mathrm{Ki}$ Ageng felt for his public. In fact, the philosopher addressed them in krama, whilst carefully avoiding the use of any honorific terms (krama inggil), overlaid with feudalistic connotations. On the contrary, the use of ngoko in short conversations or incidental comments brings the lecture to life and introduces just at the right moment a hint of familiarity, which suited the relaxed atmosphere of the meetings at which he spoke.

For Javanese people the tone of the discourse and the choice of words-particularly in regard to the emotional effect of their sounds-are extremely important. Thus, in his preface to the Indonesian translation, $\mathrm{Ki}$ Oto Suastika takes a number of precautions: "The difficulties encountered in translating this work, stem from the many terms of phrase and constructions of the spoken Javanese language which involve the concept of 'sensitivity' (rasa)." 46 As for Ki Sangoebrangta (Ki Pronowidigdo), one of the first to spread KAS's teachings (or rather his "advice," that is wejangan), he explained in a foreword to Poesara readers, that he had retained the use of the Javanese language for fear of betraying the spirit of the advice "as it related to the understanding of sensitivity and temperament" and went so far as to make excuses for having to use Latin letters (rather than Javanese characters). ${ }^{47}$

For the Kawruh Jiwa student (pelajar), Ki Ageng's teachings, whether spoken or written, were but a first step. Understanding the advice as it related to real life situations would only come after the general principles had been mastered and, above all, after sufficient thought had been given to the process of learning the principles. A student had to "understand how he understands" (ngertos caraning ngertos) in order to get to the very heart of things (nandhes), that is to arrive at a "firm" understanding (kekah pangertosipun). It mattered little that the recommendations were arranged in a pedagogical order, for they were but food for

45 Raos Pantja Sila, p. 5.

46 Cf. Filsafat rasa hidup, p. 7.

${ }^{47} \mathrm{Ki}$ Sangoebrangta, "Pendidikan oentoek ketentraman doenia, wedjangan Toeankoe Pangéran Soerjamataram (Kiai Ageng Beringin)," Poesara 1,10 (January 1932). 
thought. What was important was that the followers of the "science" should debate the ideas contained in the collection. The most experienced were to offer guidance to the novices at "meetings" (so called when even just two people met together) known as Junggring Salaka. ${ }^{8}$ In fact the period of learning was life-long: each new "misfortune" (raos cilaka) demanded to be considered in its own light and thus was it possible for one's feeling of self to be refined. It would, moreover, be wrong to think of Kawruh Jiwa as a doctrinaire approach or a Holy Word. Of fundamental importance was the purity of the learner's intentions and, even more so, of the teacher's. KAS was opposed to proselytizing zeal; he wanted his counsel to be adapted to suit the learner's needs and mental ability. Knowledge of other philosophical systems or faith in a Kebatinan doctrine was a priori a hindrance.

There were two kinds of meetings between pelajar: pasinaon and jawah kawruh. The first of these was devoted to study (sinau) and the development of the techniques of self-analysis. When they had reached the stage of feeling familiar with the principles and terminology, students could then move on to the second kind of meeting, "scientific showers" (papanggihan jawah Kawruh). These consisted of trying to help those suffering from psychological disorders by carefully analyzing with them the cause of their problems (ngudhari rerebeb: explaining the difficulty). For this kind of psycho-therapy (as it might be termed), the fourth dimension, the ability to "feel what others are feeling" was essential.

Generally, apart from these meetings which had direct and practical consequences, a pelajar had to be able, by the example he himself set, by his own personal radiance, to exert beneficial influence on his social environment.

Finally, to look at the role of the teaching "auxiliaries" which, in the case of Kawruh Jiwa, are poetry and drama: Ki Ageng himself composed a number of "songs" (uran-uran) in the macapat meter and some panembrama (songs of welcome) designed to help students to memorize the most important pieces of advice; 49 they were read or chanted collectively at meetings. As for drama, in an allegorical play-Raos Mlenet ("feeling of constraint")-KAS reiterated the most important of his ideas about marriage: that one should be free to marry the partner of one's choice. In a family there were three protagonists: father, mother, and daughter, whose choice of a future husband for the daughter had brought them into conflict with one another. Each had his own candidate. The young girl threatened to commit suicide if her parents tried to impose their choice (note that the allusion to suicide, an indication of a psychological disorder, was ever present in KAS's works). The conflict was resolved following the intervention of a local Kawruh Jiwapelajar who helped all of them to see that their points of view were governed solely by their lack of understanding of their own motivation and their selfishness.

It has already been noted that KAS found an immediate supporter of his theses in Prawirowiworo. Ki Prono, himself a former member of the Selasa Kliwon group, was also one of the first to lend his support. For Ki Haditomo, one of KAS's disciples, these two personalities, together with Ki Ageng, formed a sort of tri-tunggal in which Ki Prono represented the mind (cipta), Ki Prawiro the "heart" (manah), and Ki Ageng the body (raga).50

\footnotetext{
48 In the wayang, Junggringsalaka was designated as the home of the gods, and, by extension, the meetings held there.

49 In particular: Uran-uran Bedja.

${ }^{50}$ From an interview with Ki Haditomo (May 1975).
} 
One of the first of KAS's public lectures was reproduced and a commentary given by $M$. Soedi, ${ }^{51}$ then translated into Dutch by R. Imam Moehni in a work entitled: Inwijding tot het eeuwigdurende geluk van B.R.M. Soerjomentaram [An Introduction to lasting Happiness, by B.R.M.S. . . ; ; with a foreword dated March 9, 1930]. ${ }^{52}$ The translator gives an explanation of the Javanese terms he has retained and, in a long introduction, paraphrases and comments on the statements made by the person he still calls "Prince." It was a similar, though somewhat fuller speech, made at Surakarta in 1931, which was to form the basis of KAS's teachings. ${ }^{53}$ It could be said that KAS already had a number of pupils.

1932 onwards saw a succession of Junggring Salaka Agung-a sort of annual conference where delegations from many local pelajar organizations met together. ${ }^{54}$ Nevertheless KAS and his companions also denied having created a structured organization: local organizations were not formally constituted; followers were not required to pay subscriptions and could withdraw from their study group whenever they wished to do so (it has already been noted that just two people could hold a meeting; it was, moreover, a "non-directive" group, no-one could claim the title of guru for himself, not even Suryomentaram, whose companions merely called him "bangkokan." 55 Nevertheless, such co-ordination as was necessary was provided by regional committees, in collaboration with a central committee (Panitya Umum) located in Surakarta.

Little or no organization, therefore, but a movement which, during the 1930 s, as one conference followed another, became increasingly important. The earliest conferences seem to have given rise to a number of derisive remarks, soon quashed, however, as each new Junggring Salaka Agung prompted discussions and publications in which the doctrine became more firmly established. The conference at Yogya in 1937 was the last to be held before the war. Was the movement losing momentum? During the Japanese occupation, it is true that the country's situation hardly lent itself to philosophical discussions about personal happiness as envisaged by KAS. As has already been said, KAS, preoccupied by the power struggle with the occupying forces, became caught up in the political scene and advocated a fighting spirit which was soon to manifest itself as resistance to the return of the Dutch. Ki Ageng did not lack for supporters. In 1948, after the events at Madiun, he launched an appeal for union in Djawah Kawruh, a periodical he founded, but which was published for only two months. At the beginning of the 1950s, once peace had been reestablished, he began once more to travel about the country in order to revive the local

51 Excepting an error on the author's part; M. Soedi, Ngélmi-Kawruh-Pitedah. The 6th edition of this work includes a preface dated April 15, 1929. It is difficult to reconstruct the chronology of the earliest publications; it would appear that Uran-uran Bedja and Pangawikan pribadi (written perhaps by Prawirowiworo) date also from this time.

52 The author is grateful to Mr. K. Tsuchiya who provided this text.

53 Wedjangan.

54 The first Junggring Salaka Agung took place at Salatiga; in 1933 it was held at Surakarta, in 1934 at Kudus, in 1935 at Madiun, in 1936 at Wonosobo, and in 1937 at Yogya. After a break of thirteen years the 7th Junggring Salaka Agung was held at Magelang (1953), then at Surabaya in 1954, at Semarang in 1956, at Tulung Agung in 1957, and finally at Purwokerto in 1959. In a commemorative brochure (Buku Peringatan published for this last conference (March 21, 22, 23), an article by Kijai Pronowidigdo retraced the movement's history ("Riwajatipun Kawruh Djiwa").

55 This term is used for certain animals which, because of their strength and their age, seem to fulfil the function of "leader" of their fellow creatures. The term could here be translated as "patriarch." 
associations. He gave a number of lectures in West Java (Jakarta, Bogor, Cianjur, and Bandung) to launch his movement. ${ }^{56}$

At the 1953 Junggraing Salaka Agung in Magelang, he explained the principle of the 4th dimension, an idea which was circulated in the magazine Dudu Kowé, itself another shortlived publication. ${ }^{57} 1953$ also saw the foundation of the publishing house Windu Kentjana at Surakarta, which was to publish or re-publish Ki Ageng's lectures. This, together with the publications put out by the company C.V. Harapan at Magelang, managed by Ki Djasoewadi, ensured that the philosopher's thoughts were widely circulated and that the movement had a regular source of income. It would seem that KAS was himself able to cover his own expenses to some extent thanks to this source of income. 58

Could the movement be said to have remained totally divorced from political life, as its leaders wished? To judge from a pamphlet circulated by the Panitya K.J. from Klaten, at the time of the 1955 general elections, it would seem not. This pamphlet was in fact a poem sung to the accompaniment of the gamelan (sendhonan) and was an appeal to the people to come forward and participate in the elections, to "develop the country," and to ensure that the demands of the common people (wong cilik) were met. ${ }^{59}$ As has already been seen, KAS's lectures at this time had a distinctly nationalistic flavor (Raos Pantja Sila was a lecture delivered in 1955).

During the colonial era and the Japanese occupation the K.J. movement came under suspicion on several occasions. Once independence was achieved, pelajar were advised to exercise a degree of caution: all books studied, which were KAS's sole responsibility, had to appear upright and honest to possible investigators. 60

Although Ki Ageng often made frequent attacks on the irrational nature of the kebatinan teaching and sought to dissociate himself from it entirely, he could not prevent his movement being considered as an aliran (movement) of this kind and himself as a guru. Was this an error of judgment observers made or was it rather due to the fact that, seen from the outside and in light of the attitude of certain pelajar, the movement could have been said to exhibit all the characteristics of a "mystical sect." In any event this was the category into which it was put by Clifford Geertz, following his own observations and comments made by a K.J. "guru" from Pare. Nevertheless, to Geertz the K.J. seemed to originate from a "phenomenological analysis," and he stressed the absence of meditation which is known to be particularly important in mystical teaching. ${ }^{61}$ When Ki Ageng died, an article appeared in the periodical Varia which spoke of him as a "personality in the Kebatinan world" (tokoh di dalam dunia kebatinan). ${ }^{62}$ In the entry "Surya Mataram, Ki Ageng" in the Ensiklopedi Umum (pp. 1270-71), one finds, amongst other information: "Prince Surya Mataram (. . .) had taken

\footnotetext{
56 In 1952 in Jakarta, he spoke to the Panitya Filsafat dan Kebatinan (Philosophical and Kebatinan Committe), to the Yayasan Hidup Bahagia (Happy Life Foundation) presided over by Mr. Wongsonegoro, and to the Chinese Sam Kauw Hwee and Khong Kauw Hwee Associations.

57 It seems that the movement also published the periodical Siaran.

58 From an interview with Ki Haditomo.

59 Sendonan bab Pemilihan Umum.

60 "Manawi Junggring Salaka kedhatengan wakiling Pamarintah ingkang gadhah tugas naliti pakempalan-pakempalan lan grombolan-grombolan kanca-kanca cekap namung nyaturaken buku-buku Kawruh Jiwa wau ..." Buku Peringatan.

61 Clifford Geertz, The Religion of Java (2nd ed. Chicago and London: University of Chicago Press, 1976), pp. 34445.

62 Varia 5, 206 (March 28, 1962). The article, however, is signed by Siauw Tik Kwie, himself a pelajar and currently translating texts published by the Idayu Foundation under the name of Ki Oto Suastika.
} 
the name Ki Ageng as a guru of the aliran kebatinan known as Ilmu Begdja. His followers were spread over a large geographical area, despite a lack of organization and information, as is often the case. His teaching took the form of lectures delivered to a chosen audience in a "lesehan" manner (Jav: sitting on the ground). ..." However in 1953, the K.J. movement was not listed among the aliran kebatinan of the Daerah Istimewa Yogyakarta. ${ }^{63}$

The booklet distributed to participants at the last Junggring Salaka Agung, held in 1959 at Purwokerto, 64 contained a number of interesting facts about the conduct of the meeting; it also gave valuable information about the geographical and social origins of the movement's members.

The organization of the conference was the work of a local committee headed by $\mathrm{Ki}$ Notoamidjojo. After the evening opening ceremony, at which guests were welcomed, KAS delivered a lecture, and the play (sandiwara) Tjipta Djiwa, was performed, the conference lasted two days. KAS chaired the debates and replied to comments made by pelajar regarding the various speeches (by KAS, Ki Kartosumanto, and Ki Prono). Delegates were asked to tell the meeting of the difficulties encountered and progress made by their groups in their study of the "science," as well as their specific needs.

The publication listed 257 names and addresses of local committee members from some fifty large and medium-size towns in Java. There was a particularly large number of towns from central and eastern Java (which backs up other information given elsewhere about the movement's growth). In Temanggung, Magelang, even Jember, there were many more committees than in other places. As for the western part of the island, Jakarta, Bogor, and Bandung all had their own panitya. In addition to Java, the document listed representatives, from Madura and the Lampung area.

Except for Suryomentaram (Ki Ageng) and Prawirowiworo (Kyahi) the name pelajar was usually preceded by the particle $K i$ for men and $N y i$ for women (as is still the case in the Taman Siswa movement); women made up an extremely small percentage of delegates. Dotted about the list of names were references to the delegates' professions: pegawai (employee), guru sekolah rakyat (primary school teacher), kepala desa (village chief), mantri pengairan (irrigation worker), and even dhalang. Although certain officials lived in a kauman, there were few Muslim names. Chinese names were equally rare; and yet (judging from the advertisements placed for the most part by Chinese enterprises: batik, printing, buses, and grocery wholesalers) the financial contribution from this community toward the brochure's publication must have been substantial. It is worth remarking that there is no name ending in -ningrat (an indication of nobility) and, on the whole, the names, like the professions already cited, are typical of the so-called "lower and middle-class priyayi."

Moving on from this last congress; KAS had only three more years to live, during which time he was ill for several months. After his death, his companions in Yogya carried on the work, with Ki Atmosutidjo providing moral leadership. Several more publications were circulated. 65

Today, in the capital of the former sultanate, a K.J. group, led by Ki Haditomo, never fails to meet every thirty-five days, that is every Minggu-Pon, the day the philosopher died. It would seem that his widow, Nyi Suryomentaram, has made a point of carrying on $\mathrm{Ki}$

63 Republik Indonesia: Daerah Istimewa Jogjakarta (Jakarta: Kementerian Penerangan, 1953); cf. pp. 675-82.

64 See note 54.

65 Ki Atmosutidjo, Gandulan ... ; Ki Djojodinomo, Ular-ular . . ; Ki Suwardi Partosardjono, Sadjimpit Hatsil .. . (published by the Panitya Kawruh Jiwa in Magelang which was thus still active in 1970). 
Ageng's teaching. It is Grangsang (a son of his first marriage) who is thought of as his spiritual heir and the one who will carry on the movement. Despite his professional responsibilities (he is a Lt.-Colonel in the Navy Medical Corps) which mean that he is often called away, he endeavors, as has been seen, to expound his father's ideas, with the help of Ki Oto Suastika and the Idayu Foundation, amongst others; he is equally committed to rebuilding the movement his father began.

In the interest of contemporary history it is to be hoped that new sources or fresh evidence will shed light on Suryomentaram's role in the struggle for independence and the social reforms which accompanied the rise of nationalism, which was at first Javanese then Indonesian. Suryomentaram can be seen as quite typical of those members of the Yogya (or Surakarta) aristocracy who have been described as "enlightened priyayi," for, right from the turn of the century, these were the people who were anxious to play a leading role in promoting a new attitude, better suited to the needs of the times, and in advocating more flexible social structures than the ones which had existed during the colonial era. The attention paid to the peasants, the recognition of the essential role they play in maintaining a harmonious social entity, breathed new life into the old saying "nagara mawa tata, désa mawa cara" (organization is the work of the capital, application the work of the village).

But it is perhaps thanks to the least known aspects of KAS's biography, to its semilegendary nature, that the motives and justification for his actions, in light of the particular demands of a Javanese mentality, may best be understood. Thus it was that Prince Suryamentaram-Siddhārta left his palace to discover human misery; then began the quest of the "renouncer," which was to end in the "Awakening" (even the name of his chosen resting place, Bringin, had an underlying meaning); the Buddha-Suryamentaram showing the "middle way." There was Suryomentaram, very upset, even revolted, by the conditions he found in the kraton. His behavior was very similiar to that displayed by the classic rebel, examples of which are dotted throughout Mataram's history. His rebellion (madeg kraman) like Diponegoro's, ${ }^{66}$ for example, stemmed both from a certain moral deterioration (ineffectiveness) and from dissensions or setbacks within the family, even if, in this case, these did not have any dynastic implications. Evidence of his rebellion could be seen in the way he dressed (remember Prince Diponegoro's jubah and turban), the way he took refuge in a spiritual life and liked to frequent those places where a pact with the powers could be sealed. Diponegoro also meditated at Goa Langse and ran along the beach at Parangtritis. Such behavior may be thought of as signs of an "awakening of charisma," inspiring fearfulness. Bringin, like Tegalrejo, was a place to which he could withdraw, which enabled him to escape the court's control, and only later became the place from which a new moral order would proceed.

Times, however, had changed since Diponegoro. The awakening of a national consciousness and the liberation of the people were the goals of the new jihad. Education was the means. Suryomentaram's Indonesian editor has good reason to mention Krishnamurti.

66 On the history of Diponegoro and the idea of revolt, cf. the excellent thesis by Peter Carey (the present author has consulted a typed copy) as well as a study by the same author entitled: The Cultural Ecology of Early Nineteenth Century Java; Pangeran Dipanegara, A Case Study (Singapore: Institute of Southeast Asian Studies, 1974), 25 pp. 
Did KAS have access to his work? It seems so. ${ }^{67}$ In any event, the two shared a similar pedagogical outlook. They said to their contemporaries: "Learn to know yourself," "wisdom is mid-way between the two extremes," "you are the other person." Their discourse is timeless, universal. ${ }^{68}$ Thus, Suryamentaram was the guru; as was Ki Hajar. It was Ki Hajar, however, who had assimilated Western pedagogical theories and who wrote for the intellectuals of his generation, justifying his actions in terms of a conflict of cultures; for him Westernization was problematic; not so for Ki Ageng, who never felt the need to promote his Javanese cultural heritage.

No doubt he was too deeply immersed in it to make conscious use of it. It is not difficult, however, to find in his thinking the principal elements of a system of ethics, popular in 19th century Javanese literature, which reveals its relationship to a very old wisdom. Thus, the concept of an individual's responsibility when faced with the hazards of everyday life is reminiscent of a passage from the famous Wulang Réh, a poem by Paku Buwono IV (17881820):

Bener luput ala becik lawan begja
Cilaka apan saking
Ing badan priyangga
Dudu saka wong liya
Pramila dèn ngati-ati

(pupuh VII, durma 3)

Truth or falsehood, goodness or evil, happiness

Or misfortune, the cause is found

In each one of us

And not in another

So must we be watchful...

Similarly "detachment" (sepi ing pamrih), humility (andhap-asor), and "empathetic" understanding of others (tepa-selira $=$ KAS's 4th dimension) are principles with which readers of 19th century moral literature were equally familiar. Mawas diri, éling lan waspada, that is, that self-control is the way to ensure impeccable social behavior, was just as true for KAS as for the pujangga. The phrase "sapa temen tinememan" ("he who is just is justified") from poetic literature expresses the determination which was to be shown in all circumstances (tatag, for KAS). Many more references can be made to this literature, which is recognized as nurturing all 20th century kebatinan thought.

Why, then, did KAS give the impression of disproving the term, if not the idea? The first reason, as has been seen, stemmed from his wish to dissociate himself from the guru whose teachings, shrouded in mystery and magic, fostered self-deception and excited false hopes

\footnotetext{
67 According to Ki Haditomo (interview).

68 Many similiar remarks may be found in Krishmamurti's and KAS's writing; for example: "Do not be either attached or detached; just look at the facts, and when you understand the facts, then there is neither pleasure nor pain; there is merely the fact." (Krishnamurti On Education [Bombay: Orient Longman, 1974], p. 40).

Krishnamurti was born in 1885 . The two men were, therefore, contemporaries. They reveal the same liking for simplicity (which was also seen in Krishnamurti's style of dress) and rationalism.

It is not possible to continue the comparison further here, but it is worth noting that $K^{\prime} s$ call for the development of our sense of the aesthetic does not appear in S's work, neither does the idea that a new culture was needed (ibid., p. 37). Such a rapport, it should also be remembered, is unlikely to have been fortuitous, given the historical links between Java and India and the affinity between the two systems of thought. Moreover, for his part Ki Hajar Dewantoro used Rabindranath Tagore as his "Indian model."
} 
in their followers. It should be remembered, however, that Ki Ageng's "charisma" and aristocratic aura must often have detracted from his proclaimed intentions. ${ }^{69}$ The second reason is considerably more fundamental: is it possible to give a definition of kebatinan when God is merely incidental, as KAS does? Regarding his apparent lack of interest in religious matters, a satisfactory explanation might be that given by Moh. Said; Ki Ageng wanted to restrict himself to an "existential" philosophy: "personally I think it was because he was well aware of man's limitations in understanding what lay behind the realities of every-day life (the here and now) and not because he rejected a priori the existence of an invisible reality."70 It could also be said that if God has no part in the philosopher's thinking, it is because $\mathrm{He}$ is everywhere in it (amongst other things, in the concept of Alam Agung, the Universe).

Is it really God or Man, however, who is most important in Javanese thinking? It is definitely Man. Although spiritualist theories have borrowed from the Hindu-Buddhist religion, from Muslim mysticism or some other theosophy (sometimes even from medical science itself), in the end all these theories originate from a single psychological dictate: the spirit is the victim of a singular confusion, it is subject to a fundamental anxiety which must be quieted before inner harmony and psychological fulfilment can be found (or, if preferred, the state of vacuousness: sunya). This is a highly individualistic approach, broken into different stages (as much for the mystics as for KAS), each one of which represents some kind of advance toward the Truth, that is another step forward in one's attempts to find freedom.71 At the same time this is a sort of "psychological focalization" whose ultimate goal is spiritual peace. The "veil" must be lifted, the screen" removed, before truth is known. And truth is just as much Suryamentaram's $A k u$ as the divine presence mystics experience.

This perhaps is the perfect picture of tolerance, the celebrated Javanese tolerance, except, in fact, where dogmatic constraints are concerned ... and intolerance! The "political" implications of such an approach should not be underestimated. Personal fulfilment corresponds de facto with social achievement (in the sense of human relationships) and a balance in the relationships between the different social classes whom KAS sought to bring together, as symbolized by the black shorts and royal sarong he wore.

Such an attitude, which is but one of the "Javanese attitude[s] to life,"73 sometimes also called "priyayism," may be termed "traditional." But the taste for meditation is shared by many people in Java and, in this case, by the modest public who were attracted to KAS. Such an inclination is also highly resistant to change. Even if KAS's thoughts emerged from the mental depths where kebatinan took root, he nevertheless sought to purify them, in the strict sense of the word (to be rid of the cloak of superstition and mystic phraseology). To reason is thought of as the essential requirement for achieving psychological fulfilment; just as "modern" was the national significance KAS's thinking claimed to have. Rather than the

\footnotetext{
${ }^{69}$ It might also be helpful to look at the nature of his "revelation," the result of a long search and somewhat reminiscent of the spiritual master's wahyu.

70 Moh. Said Reksohadiprodjo, "Ki Ageng Suryomentaram," Pusara 44, 4 (April 1975): 138.

71 In the Javanese spiritual approach, De Jong distinguishes three essential components: the image of the King (Raja), "distancing" (distansi), and "representation" (representasi); see Salah satu sikap hidup orang Jawa, (Yogyakarta: Yayasan Kanisius, 1976), p. 151 (Indonesian adaptation of De Jong's thesis "Een Javaanse Levenshouding," Vrije Universiteit, Amsterdam, 1973). This author sees the concept of emancipation (distancing) as the central one, as least throughout KAS's works.

72 The idea of the "veil" or screen (warana, aling-aling), which conceals true consciousness, is common to all kebatinan theories.

73 To use De Jong's phrase (ibid).
} 
word "ngèlmu" (science with esoteric connotations), Ki Ageng preferred "kawruh" (science, in the rational sense of the word).

Translated by Susan Crossley

\section{Published lectures given by KAS and books} or articles relating to the Kawruh Jiwa.

In this bibliography, which is by no means complete, the books the author was not able to consult are included according to a "list of Kawruh Bedja" books, found at the back of certain publications. The order corresponds to the list's order, except where a date is indicated.

M. Soedi, Ngélmi-Kawruh-Pitedah Sedjatining Gesang (Wedjangan KAS), 1929 (?); Magelang, 1965 (4th ed.), 20 p. stencil.

R. Imam Moehni, Inwijding tot het eeuwigdurende geluk van B.R.M. Soerjomentaram, Djokjakarta, 71 p. (foreword written in 1930).

KAS, Uran-uran Bedja, (1930?); Surakarta, Windu Kentjana, 1955 (6th ed.), 17 p.

(KAS), Pangawikan pribadi, (1930?).

KAS, Wedjangan Kawruh Bedja sawetah, 1931 conference at Surakarta; 1957 (7th ed.), 37 p. stencil (Translated into Indonesian by Ki Oto Suastika: Wejangan pokok Ilmu Bahagia, Jakarta, Yayasan Idayu, 1975, 33 p.).

Ki Sangoebrangta (Ki Pronowidigdo), "Pendidikan oentoek ketentraman doenia wedjangan Toeanku Pangéran Soerjamataram (Kiai Ageng Beringin)," Poesara I, 10 (Jan. 13, 1932), pp. 79-81 (in Javanese).

KAS, Kawruh pamomong.

KAS, Djiwa persatuan.

KAS, Djiwa buruh.

KAS, Ilmu djiwa.

KAS, Seni Suara, 1951 Conference at Magelang; 1956 (2nd ed.), 10 p (in Indonesian).

KAS, Perang dunia kaping III, 1951 Conference at Pati; 1956 (4th ed.), 18 p.

KAS, Pandangan keadaan dunia.

KAS, Pembangunan djiwa warga negara, 1951 Conference, Surakarta, Windu Kentjana, 1955 (2nd ed.), 28 p. (in Javanese).

KAS, Aku iki wong apa?, 1952 Conference at Yogya; 1956 (4th ed.), 30 p.

KAS, Ukuran kaping sakawan, 1953 Conference at Magelang; Surakarta, Windu Kentjana, 1953 (1st ed.), 39 p. (Translated into Indonesian by Ki Oto Suastika: Ukuran Keempat, Jakarta, Yayasan Idayu, 1974, 32p.).

(KAS), Sendon Djunggring S.A. VII, 1953 (at Magelang). 
KAS, Tandesan: Wedjangan Kawruh Bedja sawetah (djilid I); Surakarta, Windu Kentjana, 1954 (1st ed.), $43 \mathrm{p}$.

KAS, Mawas diri, 1954 Conference at Surabaya; 1956 (1st ed.), 54 p.

KAS, Kawruh laki-rabi; Surakarta, Windu Kentjana, 1955 (3rd ed.), 60 p.

KAS, Piageming gesang; Surakarta, Windu Kentjana, 1955 (2nd ed.), 22 p. (Translated into Indonesian: Idjazah hidup; Jogjakarta, "Soejadi," 12 p., stencil).

KAS, Raos Pantja-Sila; Surakarta, W.K., 1955 (3rd ed.), 24 p.

KAS, Uran-uran raos Pantja Sila.

KAS, Tata negara.

KAS, Djiwa Ngajogjakarta.

KAS, Hal kesempurnaan (Indonesian text by Ki Pronowidigdo); Magelang, Harapan, 1956, $20 \mathrm{p}$.

KAS, Sandiwara Raos Mlenet; Surakarta, W.K., 1956 (1st ed.), 56 p.

KAS, Pilsapat raos gesang, 1956 Conference at Semarang; Magelang, Harapan, 1959 (2nd ed.), $17 \mathrm{p}$. (translated into Indonesian:

1) by Kjai Pronowidigdo, Pilsapat Rasa-hidup, Jogjakarta, 1957 (1st ed.), 30 p.;

2) by Ki Oto Suastika, Filsafat rasa hidup, Jakarta, Yayasan Idayu, 1974, 28 p.).

Buku Peringatan Djunggring Salaka Agung ke XI, tgl.21-22-23 Maret 1959, di Purwokerto, Panitya Dj. S.A. ke XI, Purwokerto.

Ki Djojodinomo, Ular-ular djiwa Bangsa Indonesia, Ngajogjakarta, 18 p.

Ki Atmosutidjo, Gandulan kanggé kantja-kantja peladjar-Kawruh Djiwa, Jogjakarta, 1962, 18 p. stencil.

Ki Suwardi Partosardjono, Sadjimpit Hatsil Njumerepi gagasan (pasinaon Kawruh-Djiwa babon saking Suwargi Ki Ageng Surjomentaram), Magelang, "P.K.D.," 1970, 31 p. stencil.

Moh. Said Reksohadiprodjo, "Ki Ageng Suryomentaram, 20 Mei 1892-18 Maret 1962," Pusara 44, 4 (April 1975), p.137-39. 
